\title{
Some of The Social And Personal Characteristics of The Students As Predictors of Their Value orientations
}

\author{
Lulzim Murtezani(PhD), dr. Gordana Stankovska $(\mathrm{PhD})$ \\ University of Tetova, Macedonia,Suggested reviewer: Prof.
}

\begin{abstract}
The values and value orientations are an important aspect of the behaviour of the young. The way they interpret reality: the social circumstances, other people, and also themselves, is significantly determined by what they consider as a value. This paper treats the question about the values of the young in relation with the fundamental dispositions of the personality (extroversion - introversion; neuroticism and psychoticism) and the educational climate in the family. The sample of this research includes 117 high school students aged 17 and 18 . We used the following instruments: the scale for measuring value orientations and EPQ. Contrary to the expectations, regarding the education of the parents, we found statistically significant differences among the respondents regarding the two following orientations (out of a total of 10): the popular and egoistical lifestyle. Similarly, regarding the personality traits, we found a significant connection of the following characteristics: Psychoticism, with a religious style; Extroversion, again with a religious style, and neuroticism with a religious and an egotistical style; According to the results of the introversion characteristic, we did not find significant differences among the respondents. These results show the complex nature of the connection among the value orientations, the personality traits and the educational climate in the family.
\end{abstract}

Key words: value orientation, social characteristics, personality traits, predictors, degree of preference, lifestyles.

\section{INTRODUCTION}

Modern psychologists consider the personality to be a specific structure of thinking, feeling and acting (Myers, 1998). They try to describe and explore the human personality in order to be able to anticipate the actions. Therefore, when all this is described, they start with a list of the human personality traits - individual personal qualities (Eysenck, 1992., McCrae R., R. Costa, 1987). These personality traits do not only influence the actual behaviour of the people, but also their values and value orientations (Dodd, 1951., Morris, 1956), based on which, people interpret reality.

Scientists point out the most important sources which, according to them, render people different, in terms of the values they prefer. The first source refers to the needs or the innate temperament (Rokeach, 1973,1979., McCrae, et al, 2000). They set the boundaries of the value priorities, which the group successfully socializes or transfers. The second source is the social experience of the individuals as a result of their education, age, gender, profession, etc., which directly determines their value priorities (Inglehart, 1997, Kohn, 1989, Schwartz, 1992, Schwartz \& Bardi, 1997). According to this logic, the value behaviour of the individuals is a result of a mosaic of different agents which are, above all, internal (of the personality) and external environmental cultural (Havelka, 1995., Arnaudova, 1998., Murtezani, 2002., Frichand, 2007.).

The internal characteristics are undisputed in the development of the human performances, however, they are not unique. We believe that it is necessary to also explore its external agents, in order to better understand the behaviour of the young. For an example, our assumptions show that apart from the personality and the abilities, the influence of the context, i.e. the cultural factors on the value orientations of the young, is also very important as one aspect of the behaviour. From the range of different social-demographic factors, we consider that the education of the parents significantly influences the value orientation of the people.

The degree of accepting the parents' philosophy of education is also significantly influenced by the personal factors which primarily refer to the temperament and the personality traits. Therefore, very often significant differences in the behaviour of siblings raised in the same family are noticed. This, in fact, was a reason for our paper to also focus on some personality factors - the personality traits as important determinants of the value orientations of the high school students, in our paper, apart from the education of the parents. 


\section{RESEARCH METHOD}

In accordance with the purpose of the scientific - research project, we used the

non-experimental research method.

\subsection{Subjects and data gathering procedures}

The sample of the research includes students (a total of 117) aged 17 and 18, from high schools in two cities in western Macedonia (Tetovo and Gostivar).

\subsection{Instrument}

We used two instruments for the purposes of the research. The Linkert type scale for measuring value orientations, which contains the lifestyles and the EPQ scale (Eysenck, 1997) to access the dominant personality traits.

\subsection{Processing of the research data}

The processing and analysis of the empirical data are carried out with the help of descriptive statistics (Arithmetic mean and standard deviation) and Analysis of the Variance compared with the results subjected to the non-parametric Kruskal-Wallis test.

\section{RESULTS}

\subsection{Preference of the lifestyle and education of the parents}

The social climate in the family plays an important role in the education of the children. Especially the mothers, who care about creating an educational atmosphere, which enables intellectual stimulation of the child, contribute in making their children competitive (White, 1959). The famous psychoanalyst S. Freud (According to Roth, 1989), gave great importance to the family in the development of the child. However, the influence of the parents on their children (and vice versa) has a different nature in the period of adolescence. There are many factors and circumstances, sometimes even uncontrolled, which mediate the transfer of values from the parents to the children. This, above all, refers to the peers, media and other social events. Duvan and Adelson discovered that the adolescents in the USA, are more affected with the disapproval of their decisions by their parents, than by their peers. Thus, they appreciate their opinion. (Scabini, 2006). Meisner finds that the high school students are satisfied with their parents and their discipline measures (according to Roth, 1989). After all, the relations between the parents and their children, i.e. adolescents, cannot be reduced only to the generation gap. The invisible side of these relations contains relatively high levels of respect and mutual functioning. In this context, we assume that the more educated parents, apart from other things, also nurture a more pronounced eagerness of the children to explore the environment. This is a way of marking the readiness for a more individual value orientation. However, in our case, we did not find important indicators regarding the influence of the educational family climate on the value preferences of the young (Table 1). Namely, regarding the degree of education of the fathers, we did not manage to confirm that it represents a relevant factor in the value orientations of the children. However, during the analysis of the results regarding the education of the mother, we found significant statistical differences (ANOVA) regarding the utilitarian (in favour of the respondents with mothers who have low and the ones who have high education), and the popular lifestyle, where we found significant $\mathrm{F}$ regarding the level of significance 0.01, i.e. 0.05 (Table 1). The respondents, whose mothers have high education, give more importance to these lifestyles, rather than their peers, whose mothers have low levels of education.

Table 1. ANOVA of the education of the mother and the value preferences

\begin{tabular}{|l|l|l|l|l|l|l|}
\hline Variables & $\begin{array}{l}\text { Source } \\
\text { variance }\end{array}$ & $\begin{array}{l}\text { Sum of } \\
\text { Squares }\end{array}$ & Df & $\begin{array}{l}\text { Mean } \\
\text { Square }\end{array}$ & F & Sig. \\
\hline \multirow{4}{*}{ Util. } & Between Groups & 19.329 & 2 & 9.664 & 8.265 & .000 \\
\cline { 2 - 7 } & Within Groups & 133.304 & 114 & 1.169 & & \\
\cline { 2 - 7 } & Total & 152.632 & 116 & & & \\
\hline \multirow{3}{*}{ Pop. } & Between Groups & 17.018 & 2 & 8.509 & 3.424 & .036 \\
\cline { 2 - 7 } & Within Groups & 283.290 & 114 & 2.485 & & \\
\cline { 2 - 7 } & Total & 300.308 & 116 & & & \\
\hline
\end{tabular}

This tendency speaks in favour of the assumption, that the mothers with university education nurture a high degree of ambition of their children.

\subsection{Value orientations and personality features}

Very often, when we describe the personality of a person, we point to the characteristics which render the given person different from the other people, even unique - specific. This aspect of the personality points to the individual differences among the people, which is the main subject of study of some theories. These perceptions devote significant attention to the questions regarding the personality, the characteristics, as well as 
the tests which could be used to classify them or to compare the people: some people are neurotic, some are not, some are more introverted, some are more extroverted, etc. It is considered that the personality traits, which show moderate extroversion and normality, prepare the young to better deal with the modern challenges.

This research deals with the individual differences with the purpose to analyse the proportion of the value orientations of the young. According to this, we expected to find significant differences among the respondents regarding some of their value orientations as a result of their different characteristics. We believe that exactly these characteristics significantly influence the way in which the young understand the values, and develop orientations in their lives according to them. Therefore, we expect the comparison of the respondents with different scores on the personality tests, to show differences among them, in terms of their value orientations as well.

During the data processing, contrary to our expectations about the majority of the offered value orientations, we did not find statistically significant differences among the respondents with different basic personality dimensions. The value orientations of this type present an exception: religious, family and egoistical style, which are significantly related to the dimensions psychoticism, extroversion and neuroticism (Tables 2,3, and 4).

Table 2. ANOVA of the dimension psychoticism and the variables (value orientations)

\begin{tabular}{|l|l|l|l|l|l|l|}
\hline Variables & $\begin{array}{l}\text { Source } \\
\text { variance }\end{array}$ & $\begin{array}{l}\text { Sum of } \\
\text { Squares }\end{array}$ & Df & $\begin{array}{l}\text { Mean } \\
\text { Square }\end{array}$ & F & Sig. \\
\hline $\begin{array}{l}\text { Religious } \\
\text { style }\end{array}$ & Between Groups & 45.871 & 28 & 1.638 & 1.636 & .029 \\
& & & & & & \\
\cline { 2 - 8 } & Within Groups & 197.226 & 197 & 1.001 & & \\
\cline { 2 - 8 } & Total & 243.097 & 225 & & & \\
\hline
\end{tabular}

The F is statistically significant only when related to the religious style. Most probably, the people who chose this style, are the most comfortable when respecting the religion.

Table 3. ANOVA of the dimension extroversion and the variables (value orientations)

\begin{tabular}{|l|l|l|l|l|l|l|}
\hline Variables & $\begin{array}{l}\text { Source } \\
\text { variance }\end{array}$ & $\begin{array}{l}\text { Sum of } \\
\text { Squares }\end{array}$ & Df & $\begin{array}{l}\text { Mean } \\
\text { Square }\end{array}$ & F & Sig. \\
\hline \multirow{2}{*}{$\begin{array}{l}\text { Religious } \\
\text { style }\end{array}$} & Between Groups & 50.187 & 26 & 1.930 & 1.991 & .004 \\
\cline { 2 - 7 } & Within Groups & 192.911 & 199 & .969 & & \\
\cline { 2 - 7 } & Total & 243.098 & 225 & & & \\
\hline
\end{tabular}

There is a statistically significant relationship between the extroversion and the religious lifestyle (at a level of $0.05)$

Table 4. ANOVA of the dimension neuroticism and the variables (value orientations)

\begin{tabular}{|l|l|l|l|l|l|l|}
\hline Variables & $\begin{array}{l}\text { Source } \\
\text { variance }\end{array}$ & $\begin{array}{l}\text { Sum of } \\
\text { Squares }\end{array}$ & Df & $\begin{array}{l}\text { Mean } \\
\text { Square }\end{array}$ & F & Sig. \\
\hline \multirow{2}{*}{$\begin{array}{l}\text { Egoistic } \\
\text { style }\end{array}$} & Between Groups & 82.145 & 24 & 3.423 & 1.562 & .050 \\
\cline { 2 - 7 } & Within Groups & 442.762 & 202 & 2.192 & & \\
\cline { 2 - 7 } & Total & 524.907 & 226 & & & \\
\hline \multirow{2}{*}{$\begin{array}{l}\text { Religious } \\
\text { style }\end{array}$} & Between Groups & 39.748 & 24 & 1.656 & 1.637 & .036 \\
\cline { 2 - 7 } & Within Groups & 203.349 & 201 & 1.012 & & \\
\cline { 2 - 7 } & Total & 243.097 & 225 & & & \\
\hline
\end{tabular}

There is a significant $\mathrm{F}$ only regarding the egoistical lifestyle and the religious lifestyle at the level of 0.05 . We did not find any statistically significant relations about the other lifestyles.

\section{CONCLUSIONS AND A SUGGESTION}

2.2. Apart from the initial expectations about the existence of significant differences in the degree of preference of the value orientations of the respondents as a result of the education of the parents, generally, they were not confirmed. We found a significant difference only regarding the utilitarian and popular lifestyles of the respondents, with mothers with a high level of education. Do these data support the assumption that the family educational climate has a small role in the value orientations of the young? We believe that the best 
answer to this question is the one, according to which, other controlled and sometimes uncontrolled factors influence the value orientations of the young, along with the educational climate in the family. We assume that the personality differences themselves, are one of the most important sources for the value diversity of the people, including the adolescents. According to this, we expected certain personality traits to make the people more sensitive regarding some value orientations, rather than other traits. The results of the research insignificantly confirmed these expectations. This does not mean that the traits are not important for the value orientations, but that their influence is intertwined with other factors.

Generally speaking, while interpreting the results of the research, they should be a target for some limiting factors, regarding researches which use instruments of the self-declaration type. This examination of the psychological factors does not imply that they are the most representative regarding the choice of the value orientations. In many real situations, the personality is determined by the situation factors, especially during times of crisis and confusion.

\subsection{Suggestion}

It is well known that the values can make the people orient towards the future, past or present. Every society, through the educational programs and other ways of socialization, strives to approach the values which the modern cultures rely on.

Therefore, knowing the dominant value orientations of the young, their diversity and the relation to the different factors, offers us a possibility to educate the values and the value orientations of the children and the young in the direction of the new world trends in the society.

\section{LITERATURE}

Arnaudova, V. (1998). The influence of the transition on the value system of the young. Annual book of the Faculty of Philosophy. pp. 83-94.

Myers, D.G (1998). PSYCHOLOGIE. New York: Worth Publishers.

Dodd, S. (1951). On Classifying Human Values a step in the prediction on Human Valuing. American Sociological Review. 16 p. 645-653.

Eysenck, H.J. (1992) Four ways five factors are not basic. Personality and individual Differences. Vol. 3\13, 667-673.

Eysenck, H.J. (1997) Personality and experimental psychology: The unification of psychology and the possibility of a paradigm. Journal of Personality and Social Psychology, 73. 1224-1237.

Frichand, A.(2007) Values, value orientations, moral attitudes and models for identifications in age groups. Master's paper: Skopje

Havelka, N. (1995). Vrednosne orijentacije učenika i njihova očekivanja od budućeg zanimanja. Psihološka isrtaživanja 7. Beograd: Filozofski fakultet

Inglehart, R. (1977). The silent revolution. Princeton, NJ: Princeton University Press.

Inglehart, R. (1997). Modernization and postmodernization. Princeton, NJ: Princeton

Mc. Crae R.R.Costa T.P.Jr. (1987) Validation of the five-factor model of personality across instruments and observers. Journal of Personality and Social Psychology, 52, 81-90.

Morris, C.W. (1956). Varieties of human value. Chicago: University of Chicago Press.

Murtezani, L.(2002) Value preferences of the adolescents. Master'spaper. Skopje

Rokeach, M. (1973). The nature of human values. New York: Free Press.

Rokeach, M. (1979). Understanding human values. New York: Free Press.

Roth, N. (1989). Osnovi socijalne psihologije. Beograd: Zavod za udžbenike i nastavna sredstva

Scabini, E. \& Marta, E. (2006).Changing intergenerational relationship. European Review, Vol. 14, No.1, 81 98. Academia Europea (EBSCO, internet database, Acedemic Search Premier)University Press.

Schwartz, S. H. (1992). Universals in the content and structure of values: Theory and empirical tests in 20 countries. In M. Zanna (Ed.), Advances in experimental social psychology (Vol. 25) (pp. 1-65). New York: Academic Press.

White, R. W( 1959) Motivation reconsidered:The concept of competence.Psychologycal review 66.297-333. 